\title{
The Undergraduate College Education in USA: Schools with Best and Worst ROI
}

\author{
Raj K. Kohli \\ Professor of Finance \\ Judd Leighton School of Business and Economics \\ Indiana University South Bend
}

\begin{abstract}
This study examined the ROI, total 4-year education cost, graduation rate and average loan amount for undergraduate education across schools in USA. The results indicate that students from Southwest region of USA enjoyed highest mean ROI (6.69\%) along with highest median ROI (6.50\%) with minimum standard deviation of $2.03 \%$ among all five regional analyzed over 20 -yeasr period. Yale University reports the highest graduation rate of 98 percent in the nation. Georgia Institute of Technology (In-state) enjoyed highest ROI of 12.30 percent over 20-years period of study.
\end{abstract}

Keywords: College ROI Cost Graduation Undergraduate

\section{BREIF LITERATURE REVIEW}

The cost of an undergraduate college education has been rising each year. The basic economic question is the time required to pay back educational debt after entering the workforce in USA. Allie Bidwell (February 2015) writes "It's a strange paradox. At a time when Americans overwhelmingly say it's important to receive a college education, their faith in the economic value of the investment is slipping, new research shows. A survey of more than 2,000 adults 900 of whom were college graduates - released Tuesday by education technology company Greenwood Hall, shows more than half of graduates say those leaving college with a degree now will see a lower return on their education investment than those 10 to 15 years ago. Simply put, while the cost of college continues to rise and the economy is slowly coming out of the Great Recession, today's graduates might not get as much bang for their buck."

Students may have piled a huge education debt loan upon graduation. $70 \%$ of graduating seniors will enter the workforce with an average student loan debt of $\$ 29,400$ (Carrie SealyMorris 2016). Hence, the question of ROI on college education is very important for graduates. ROI for a college degree is different than ROI of an investment/project due to opportunity costs; like students' time, working possibilities, and lost entertainments. In addition, students also have to study continuously and go through stress and pressure of regular assignments and exams. Thus, ROI on college education may be different than business's ROI.

Carrie Sealy-Morris (2016) writes "There are a lot of factors to take into consideration. You invest a lot more than just money into a college education - you invest time, work, and stress. That makes college fundamentally different from many other investments. ROI could be as simple as what income people make vs. what they paid for college and what they owe in student debt, but that is still too simple. Income isn't necessarily a measure of success, and student loan debt could just mean you took out more loans than you needed, not that the school was too expensive. While some short sighted people just want to know how much 
money they can make straight out of school, others want a certain level of long-term career satisfaction. Neither is wrong."

Studies like PayScale's help would-be students (and their parents) make more informed choices. As Americans start to realize how much a bad choice can hurt them, they will demand more transparency. Some colleges are providing it, prodded by the federal government. For example, the University of Texas recently launched a website showing how much its graduates earn and owe after five years. (The Economist: Higher Education-6).

In the past, college education used to lead to better, brighter, and financially lucrative professional careers. However, in the present times, undergraduate education may not act as a ticket to better careers but may also result in significant educational loans upon graduation. According to the Federal Reserve Bank of New York, 44 percent of recent college graduates are underemployed -- working in jobs that don't require their degree -- as of 2012 (PayScale College ROI Report: Best Value Colleges: www.payscale.com/college-roi)

In spite of numerous articles printed in magazines, academic journals lack the analytical research on this topic. Therefore, this study is an initial step to analyze ROI and other factors relevant to students' educational goals from an academic point.

\section{DATA AND METHODOLOGY}

The data is collected from information collected by Payscale.com's list of ROI rankings. Payscale.com website provides useful information on ROI and other factors important to college graduates. PayScale.com administers the largest real-time salary survey in the world with more than 150,000 new survey records added every month. The database of more than 54 million total salary profiles is updated nightly to reflect the most detailed, up-to-date compensation information available. Payscale.com data collection is strongly correlated with the size of the pool being considered, representing the diversity of the general workforce.

Both in-State and out-of-State educational institutions are included in this study. The following four variables (factors) are analyzed in this study:

1. Total 4-Year Cost (Principal Amount Invested): Full cost including tuition \& fees, room \& board and books \& for a 2014 graduate. Actual net cost may vary based on a student's academic success and family income. Source: IPEDS. This variable is analyzed separately and is also used in computing ROI.

2. 20 Years ROI (Gain in Dollars over 20 Years Period after graduation): Difference between 20 years Median Pay for a bachelor's grad and 24year Median pay for a high school grade minus total 4-year cost. This variable is not analyzed separately but is used in computing ROI.

3. Graduation Rate: Percent of full-time, first-time degree seeking undergraduate students who began their studies at the given school and graduate within 6 years. Source: IPEDS

4. Average Loan Amount: Received by full-time, first time degree seeking undergraduate students for the 2012-2013 school year, multiplied to represent amount over 4 years. Includes all Title IV loans and all institutionally and privately-sponsored student loans. Source: IPEDS

5. Annualized Return on Investment (ROI) Formula

Annual Percentage Yield $($ APY $)=($ principal + gain $/$ principal $)(1 /$ years $)-1$ 
For example:

Look at Indiana University Bloomington (in-State education)

20 -Year Net ROI $=\$ 303,000$ (Gain over 20-years period)

Total 4-Year Cost $=\$ 90,000$ (Principal)

$\mathrm{APY}=(\$ 393,000 / 90,000)(1 / 20)-1=4.36660 .05-1=1.076483-1=7.65 \%$

Thus, ROI for Indian University Bloomington (in-State) graduate is $7.65 \%$ over a period of 20 years after graduation and entering the workforce.

The data is collected for 1,278 educational institutions across USA. However, incomplete data for 64 schools was dropped thereby reducing dataset to 1,214 schools. The data is also further divided in the five categories as follows:
a. Midwest Region
b. Southeast Region
c. Northeast Region
d. Southwest Region
e. West Region

\section{All schools in USA}

\section{RESULTS}

The results of the analysis across all schools in USA are shown in Table 1 which shows that the mean annual ROI for undergraduate education in USA is 5.39 percent over the last twenty-year period with a standard deviation of 2.64 percent. The median annual income over the same period is found to be 5.50 percent.

The graduates from Georgia Institute of Technology (In-State) earned the highest annual ROI of 12.30 percent per year for 20 years, while Jackson State University, Mississippi (Out-of-State) graduates earned an average ROI of $-10.30 \%$. Comparison of total 4-year cost of education reveals that students at University of Chicago (Private) spent a total of $\$ 245,000$ while the total of cost education $(\$ 46,500)$ at Elizabeth City State University of North Carolina was the cheapest among all schools in USA.

Yale produced highest graduation rate of 98 percent for the undergraduate students, while students at Baker College Flint MI were graduating at the lowest rate of 11 percent during the study period. The students at Clemson University (Out-of-State) took the highest loan of $\$ 51,600$ during their undergraduate educational life. On the other side, students at Colgate University (Private) were able to graduate with a minimum average loan of $\$ 9,600$ only.

\section{Schools in Midwest Region}

Table 2 (Panel A) shows the results for schools in Midwest Region. Data for 319 schools is used and incomplete data of 13 schools is excluded in this group.

The findings of this study indicate that the mean annual ROI for undergraduate education in Midwest region is 5.19 percent over the last twenty-year period with a standard deviation of 2.51 percent. Both these percentages are below the national average indicating that mean ROI is lower than national average with a tighter probability distribution. The median annual income is 5.35 percent which is slightly smaller than the national average.

The graduates from South Dakota School of Mines and Technology (In-State) earned the highest annual ROI of 11.94 percent per year for 20 years, while Ashland University (Private) of Ohio's graduates earned an average ROI of $-3.30 \%$. In this group of schools, students at 
University of Chicago (Private) had to spend 4-year education cost of $\$ 245,000$ (which is also the highest in USA), whereas students at Missouri Southern State University faced the cheapest 4-year educational expense of $\$ 58,900$.

The highest graduation rate of 95 percent was reported by University of Notre Dame (Private), while students at Baker College Flint MI were graduating at the lowest rate of 11 percent during the study period (which is also lowest in USA). The students at Kettering University (Private) of Michigan had to take the highest educational loan of $\$ 45,600$. But, the students at Drury University (Private) of Missouri took the lowest loan of $\$ 16,160$ during their educational life.

\section{Schools in Southeast Region}

This study's results for schools in Southeast region are reported in Table 2 (Panel B). Data for 323 schools is used and incomplete data of 18 schools is excluded.

The results shown in this project suggest that the mean annual ROI for undergraduate education in Southeast region is 4.98 percent over the last twenty-year period with a standard deviation of 3.02 percent. While mean ROI is lower than national average, the standard deviation is higher national norms. Thus, according to findings of this study, mean ROI of this group is lower than national average with much wider distribution indicating relatively poor performance of the group. The median annual income is 5.19 percent which is smaller than national average.

The graduates from Georgia Institute of Technology (In-State) earned the highest annual ROI of 12.30 percent (which is also the highest in nation) per year for 20 years, while Jackson State University, Mississippi (Out-of-State) graduates earned an average ROI of $-10.16 \%$ (which is also the lowest across USA).

In this group of schools, students at Georgetown University-Washington DC (Private) ended up paying $\$ 236,700$ (highest) for their 4-years education as compare to the lowest educational expenses of only $\$ 46,500$ at Elizabeth City State University (In-State) which is also the smallest educational cost in nation.

Students at Duke University enjoyed the highest graduation rate of 94 percent, while students at West Virginia State University (both In-State and Out-of-State) had to settle with the lowest graduation rate of 19 percent. Students at Clemson University (both In-State and Out-of-State) took highest loan of $\$ 51,600$ (which is also the highest for nation). In contrast, Southern University and A\&M College (both In-State and Out-of-State) were able to graduate with the minimum educational loan of mere $\$ 12,760$.

\section{Schools in Northeast Region}

Table 2 (Panel C) shows the results of this project for schools in Northeast region. Data for 299 schools is analyzed in this group whereas incomplete data of 19 schools is excluded in this project.

Mean annual ROI for undergraduate education in this region is 5.20 percent over the last twenty-year period with a standard deviation of 2.19 percent. Similar to Midwest region, both these percentages are below national average indicating that mean ROI is lower than national average with a tighter probability distribution. The median annual income is 5.31percent lower than the national norms. Massachusetts Maritime Academy (In-State) graduates were 
able to earn the highest annual ROI of 11.52 percent for 20-years period, while Centenary College (Private) of New Jersey graduates earned minimum ROI of $-2.07 \%$.

In this group of schools, students at Columbia University (Private) paid $\$ 241,600$ (highest) for their 4-years education as compare to the lowest educational expenses of \$77,300 00 at Rhode Island College (in-State). Yale University graduates enjoyed a graduation rate of 98 percent (highest in the nation), while students of Long Island University Brooklyn (private) faced the lowest graduation rate of 30 percent only. University of New Haven (private) students took the highest loan of $\$ 49,200$, while Colgate University (private) graduates were able to graduate with minimum educational loan of mere $\$ 9,760$ (which is also lowest in USA).

\section{Schools in Southwest Region}

Table 2-Panel D shows that data for 323 schools is analyzed in this group while incomplete data of 18 schools is excluded

Mean annual ROI for undergraduate education in this region is 6.69 percent much higher than national average with a standard deviation of 2.03 percent much lower than national average. In fact, this group has the highest mean ROI and lowest standard. The median annual income is 6.50 percent which is also highest among all regions. Thus, the results reported in this analysis indicate that graduates of Southwest region enjoyed highest return with least risk among all five regions studied.

New Mexico Institute of Mining and Technology (In-State) graduates received highest ROI of 11.87 percent while the lowest ROI of only $0.25 \%$ belonged to the graduates of Oral Roberts University of Oklahoma. Southern Methodist University (Private) students faced highest educational cost of $\$ 229,300$ whereas students at Northeastern University (In-State) of Oklahoma were able to graduate with a minimum cost of $\$ 53,300$. Highest graduation rate of $91 \%$ is enjoyed by Rice University students while graduates at Texas Southern University had to settle with the lowest graduation rate of 16 percent.

Comparison of average loan for graduation shows a tie between Baylor University (private) and Texas Southern University (In-State) for loan of $\$ 50,400$. In contrast, students at University of Texas -Pan American (IN-State) graduated with a minimum loan of $\$ 15,320$.

\section{Schools in West Region}

This study's results for schools in West region are reported in Table 2 (Panel E). Data for 178 schools is used and incomplete data of 11 schools is excluded.

The results shown in Table suggest that mean annual ROI for undergraduate education in West region is 6.09 percent over the last twenty-year period with a standard deviation of 2.79 percent. While mean ROI is higher than national average, the standard deviation is also higher than national norms. Thus, according to findings of this study, mean ROI of this group is higher than national average with much wider distribution. Median ROI for the group is $6.08 \%$ which is also higher than national average. A closer look at table 2 also indicates that colleges in West region are second to colleges in Southwest as per ROI ranking.

Graduates of Brigham Young University earned highest ROI of 12.28 percent while Adams State College (Out-of-State) graduates earned minimum ROI of -6.96 percent. The maximum educational cost of $\$ 238,100$ belonged to graduates of Occidental College, whereas students at University of Alaska (Fairbanks campus) were able to graduate with a minimum cost of $\$ 66,300$. 
Highest graduation rate of $96 \%$ is reported at Stanford University while students at Adams State College (both In-State and Out-of-State) received the lowest graduation rate of 23 percent. Maximum educational loan of $\$ 45,600$ was taken by graduates of Dominican University of California whereas graduates at California State University-Los Angeles (both InState and Out-of-State) were able to graduate with a minimum loan of $\$ 16,420$.

\section{CONCLUSION}

The results of this study indicate that students from Southwest region of USA enjoyed highest mean ROI (6.69\%) along with highest median ROI (6.50\%) with minimum standard deviation of $2.03 \%$ among all five regional analyzed over 20-yeasr period. Colleges in West region are second to colleges in Southwest as per ROI ranking. Students of colleges in Northeast region had to pay the highest educational cost $(\$ 152,577)$ over the period of study but they also enjoyed the highest graduation rate of $63.22 \%$ among five regions. Yale University reports the highest graduation rate of 98 percent in the nation. Georgia Institute of Technology (In-state) enjoyed highest ROI of 12.30 percent over 20 -years period of study.

Table I: Undergraduate College Degree's Return on Investment across Schools in USA

\begin{tabular}{|l|c|c|c|}
\hline & \multicolumn{1}{|c|}{ Mean } & \multicolumn{1}{c|}{ Standard Deviation } & Median \\
\hline Annual ROI & $5.39 \%$ & $2.64 \%$ & $5.50 \%$ \\
\hline Total 4 Year Cost & $\$ 130,233$ & $\$ 47,642$ & $\$ 121,900$ \\
\hline Graduation Rate & $56.71 \%$ & $17.06 \%$ & $55.00 \%$ \\
\hline Average Loan Amount & $\$ 27,878$ & $\$ 5,642$ & Value \\
\hline For the Group & Name of School & $12.30 \%$ \\
\hline Maximum Annual ROI & Georgia Institute of Technology(In-State) & $-10.16 \%$ \\
\hline Minimum Annual ROI & Jackson State University (JSU)(Out-of-State)-MS & $\$ 245,000$ \\
\hline Maximum Total 4 Year Cost & University of Chicago(Private) & $\$ 46,500$ \\
\hline Minimum Total 4 Year Cost & Elizabeth City State University (ECSU)(In-State)-NC & $98.00 \%$ \\
\hline Maximum Graduation Rate & Yale University(Private) & $11.00 \%$ \\
\hline Minimum Graduation Rate & Baker College - Flint, MI(Private) & $\$ 51,600$ \\
\hline Maximum Average Loan Amount & Clemson University(Out-of-State) & $\$ 9,680$ \\
\hline Minimum Average Loan Amount & Colgate University(Private)-NY & $1214 *$ & \\
\hline Total Number of Schools & \multicolumn{1}{|l}{} \\
\hline$*$ Data for additional 64 schools was incomplete and hence dropped from the analysis & \\
\hline
\end{tabular}

Table II (Panel A): Undergraduate College Degree's Return on Investment Across Schools in Midwest

\begin{tabular}{|c|c|c|c|}
\hline & Mean & Standard Deviation & Median \\
\hline Annual ROI & $5.19 \%$ & $2.51 \%$ & $5.35 \%$ \\
\hline Total 4 Year Cost & $\$ 124,471$ & $\$ 42,734$ & $\$ 120,200$ \\
\hline Graduation Rate & $54.97 \%$ & $15.82 \%$ & $54.00 \%$ \\
\hline Average Loan Amount & $\$ 27,916$ & $\$ 4,833$ & $\$ 27,440$ \\
\hline For the Group & \multicolumn{2}{|l|}{ Name of School } & Value \\
\hline Maximum Annual ROI & \multicolumn{2}{|c|}{ South Dakota School of Mines \& Technology(In-State) } & $11.94 \%$ \\
\hline Minimum Annual ROI & \multicolumn{2}{|c|}{ Ashland University(Private)-OH } & $-3.30 \%$ \\
\hline Maximum Total 4 Year Cost & \multicolumn{2}{|c|}{ University of Chicago(Private) } & $\$ 245,000$ \\
\hline Minimum Total 4 Year Cost & \multicolumn{2}{|c|}{ Missouri Southern State University (MSSU)(In-State) } & $\$ 58,900$ \\
\hline Maximum Graduation Rate & \multicolumn{2}{|c|}{ University of Notre Dame(Private) } & $95.00 \%$ \\
\hline
\end{tabular}




\begin{tabular}{|l|l|r|}
\hline Minimum Graduation Rate & Baker College - Flint, MI(Private) & $11.00 \%$ \\
\hline Maximum Average Loan Amount & Kettering University(Private)-MI & $\$ 45,600$ \\
\hline Minimum Average Loan Amount & Drury University(Private)-MO & $\$ 16,160$ \\
\hline \multicolumn{1}{|c|}{ Total Number of Schools } & \multicolumn{1}{|c|}{$319 *$} & \\
\hline$*$ Data for additional 13 schools was incomplete and hence dropped from the analysis & \\
\hline
\end{tabular}

Table II (Panel B): Undergraduate College Degree's Return on Investment Across Schools in Southeast

\begin{tabular}{|c|c|c|c|}
\hline & Mean & Standard Deviation & Median \\
\hline Annual ROI & $4.98 \%$ & $3.02 \%$ & $5.19 \%$ \\
\hline Total 4 Year Cost & $\$ 116,972$ & $\$ 41,851$ & $\$ 107,400$ \\
\hline Graduation Rate & $51.04 \%$ & $18.11 \%$ & $48.00 \%$ \\
\hline Average Loan Amount & $\$ 26,704$ & $\$ 5,358$ & $\$ 26,840$ \\
\hline For the Group & \multicolumn{2}{|l|}{ Name of School } & Value \\
\hline Maximum Annual ROI & \multicolumn{2}{|c|}{ Georgia Institute of Technology(In-State) } & $12.30 \%$ \\
\hline Minimum Annual ROI & \multicolumn{2}{|c|}{ Jackson State University (JSU)(Out-of-State) } & $-10.16 \%$ \\
\hline Maximum Total 4 Year Cost & \multicolumn{2}{|c|}{ Georgetown University - Washington D.C.(Private) } & $\$ 236,700$ \\
\hline Minimum Total 4 Year Cost & \multicolumn{2}{|c|}{ Elizabeth City State University (ECSU)(In-State) } & $\$ 46,500$ \\
\hline Maximum Graduation Rate & \multicolumn{2}{|c|}{ Duke University(Private) } & $94.00 \%$ \\
\hline Minimum Graduation Rate & \multicolumn{2}{|c|}{ West Virginia State University(Both: In-State and Out-State) } & $19.00 \%$ \\
\hline $\begin{array}{lll}\text { Maximum } & \text { Average } & \text { Loan } \\
\text { Amount } & & \\
\end{array}$ & \multicolumn{2}{|c|}{ Clemson University(Both: In-State and Out-State) } & $\$ 51,600$ \\
\hline Minimum Average Loan Amount & \multicolumn{2}{|c|}{$\begin{array}{l}\text { Southern University and A\&M College(Both: In-State \& Out-State)- } \\
\text { LA }\end{array}$} & $\$ 12,760$ \\
\hline Total Number of Schools & \multicolumn{3}{|c|}{$323 *$} \\
\hline
\end{tabular}

Table II (Panel C): Undergraduate College Degree's Return on Investment Across Schools in Northeast

\begin{tabular}{|c|c|c|c|}
\hline & Mean & S.D. & Median \\
\hline Annual ROI & $5.20 \%$ & $2.19 \%$ & $5.31 \%$ \\
\hline Total 4 Year Cost & $\$ 152,577$ & $\$ 50,348$ & $\$ 148,300$ \\
\hline Graduation Rate & $63.22 \%$ & $16.73 \%$ & $63.00 \%$ \\
\hline Average Loan Amount & $\$ 30,469$ & $\$ 6,741$ & $\$ 30,500$ \\
\hline For the Group & \multicolumn{2}{|l|}{ Name of School } & Value \\
\hline Maximum Annual ROI & \multicolumn{2}{|c|}{ Massachusetts Maritime Academy(In-State) } & $11.52 \%$ \\
\hline Minimum Annual ROI & \multicolumn{2}{|c|}{ Centenary College(Private)-New Jersey } & $-2.07 \%$ \\
\hline Maximum Total 4 Year Cost & \multicolumn{2}{|c|}{ Columbia University(Private) } & $\$ 241,600$ \\
\hline Minimum Total 4 Year Cost & \multicolumn{2}{|l|}{ Rhode Island College(In-State) } & $\$ 77,300$ \\
\hline Maximum Graduation Rate & \multicolumn{2}{|l|}{ Yale University(Private) } & $98.00 \%$ \\
\hline Minimum Graduation Rate & \multicolumn{2}{|c|}{ Long Island University - Brooklyn(Private) } & $30.00 \%$ \\
\hline $\begin{array}{lll}\text { Maximum Average } & \text { Loan } \\
\text { Amount } & & \\
\end{array}$ & \multicolumn{2}{|c|}{ University of New Haven(Private)-CT } & $\$ 49,200$ \\
\hline Minimum Average Loan Amount & \multicolumn{2}{|c|}{ Colgate University(Private)-NY } & $\$ 9,680$ \\
\hline Total Number of Schools & \multicolumn{3}{|c|}{$299 *$} \\
\hline
\end{tabular}


Table II (Panel D): Undergraduate College Degree's Return on Investment Across Schools in Southwest

\begin{tabular}{|c|c|c|c|}
\hline & Mean & Standard Deviation & Median \\
\hline Annual ROI & $6.69 \%$ & $2.03 \%$ & $6.50 \%$ \\
\hline Total 4 Year Cost & $\$ 108,743$ & $\$ 38,354$ & $\$ 97,400$ \\
\hline Graduation Rate & $46.42 \%$ & $16.67 \%$ & $44.00 \%$ \\
\hline Average Loan Amount & $\$ 25,629$ & $\$ 6,175$ & $\$ 24,700$ \\
\hline For the Group & \multicolumn{2}{|l|}{ Name of School } & Value \\
\hline Maximum Annual ROI & \multicolumn{2}{|c|}{ New Mexico Institute of Mining and Technology (In-State) } & $11.87 \%$ \\
\hline Minimum Annual ROI & \multicolumn{2}{|c|}{ Oral Roberts University (ORU)(Private)-OK } & $0.25 \%$ \\
\hline Maximum Total 4 Year Cost & \multicolumn{2}{|c|}{ Southern Methodist University (SMU)(Private) } & $\$ 229,300$ \\
\hline Minimum Total 4 Year Cost & \multicolumn{2}{|c|}{ Northeastern State University(In-State)-OK } & $\$ 53,300$ \\
\hline Maximum Graduation Rate & \multicolumn{2}{|c|}{ Rice University(Private) } & $91.00 \%$ \\
\hline Minimum Graduation Rate & \multicolumn{2}{|c|}{ Texas Southern University (Out-of-State) } & $16.00 \%$ \\
\hline \multirow[t]{2}{*}{ Maximum Average Loan Amount } & \multicolumn{2}{|c|}{ Tie- Baylor University(Private) } & $\$ 50,400$ \\
\hline & \multicolumn{2}{|c|}{ Tie- Texas Southern University(In-State) } & \\
\hline Minimum Average Loan Amount & \multicolumn{2}{|c|}{ University of Texas - Pan American (UTPA)(In-State) } & $\$ 15,320$ \\
\hline Total Number of Schools & \multicolumn{3}{|c|}{$95 *$} \\
\hline
\end{tabular}

Table II (Panel E): Undergraduate College Degree's Return on Investment Across Schools in West

\begin{tabular}{|c|c|c|c|c|}
\hline & Mean & S.D. & \multicolumn{2}{|l|}{ Median } \\
\hline Annual ROI & $6.09 \%$ & $2.79 \%$ & & $6.08 \%$ \\
\hline Total 4 Year Cost & $\$ 137,053$ & $\$ 50,182$ & & $\$ 128,750$ \\
\hline Graduation Rate & $55.67 \%$ & $18.29 \%$ & & $53.00 \%$ \\
\hline Average Loan Amount & $\$ 24,862$ & $\$ 4,645$ & & $\$ 23,680$ \\
\hline For the Group & \multicolumn{3}{|l|}{ Name of School } & Value \\
\hline Maximum Annual ROI & \multicolumn{3}{|c|}{ Brigham Young University (BYU)(Private) } & $12.28 \%$ \\
\hline Minimum Annual ROI & \multicolumn{3}{|c|}{ Adams State College(Out-of-State) } & $-6.96 \%$ \\
\hline Maximum Total 4 Year Cost & \multicolumn{3}{|c|}{ Occidental College(Private) } & $\$ 238,100$ \\
\hline Minimum Total 4 Year Cost & \multicolumn{3}{|c|}{ University of Alaska - Fairbanks Campus(In-State) } & $\$ 66,300$ \\
\hline Maximum Graduation Rate & \multicolumn{3}{|c|}{ Stanford University(Private) } & $96.00 \%$ \\
\hline Minimum Graduation Rate & \multicolumn{3}{|c|}{ Adams State College(Both: In-State and Out-State) } & $23.00 \%$ \\
\hline Maximum Average Loan Amount & \multicolumn{3}{|c|}{ Dominican University of California(Private) } & $\$ 45,600$ \\
\hline Minimum Average Loan Amount & \multicolumn{3}{|c|}{ California State University-Los Angeles(Both: In-State \&Out-State) } & $\$ 16,240$ \\
\hline Total Number of Schools & \multicolumn{4}{|c|}{$178^{*}$} \\
\hline
\end{tabular}

\section{References}

1. Allie Bidwell, USA News, "College Grads Question How Much a Degree is Worth: More than half of college graduates say new grads will see a lower return on their educational investment," February 10, 2015.

2. Best Return on Investment "The 50 Colleges with the Best Return on Investment in 2016, www.bestcolleges.com/features/best-roi-colleges/ 
3. Carrie Sealey-Morris, "What's the ROI of a college degree? | Value Colleges," www.valuecolleges.com/whats-the-roi-of-a-college-degree/, 2016 Value Colleges.

4. Chris Kahn, "What Is The ROI Of Your College Degree? Which jobs and degrees help you to pay off your student loans fastest? Find the ROI for your college degree," Bankrate.com, www.bankrate.com/finance/college-finance/roi-college-degree.aspx

5. PayScale College ROI Report: Best Value Colleges: www.payscale.com/college-roi)

6. Payscle.com

7. The Economist: Higher education, "Is College worth it? Too many degrees are a waste of money. The return on higher education would be much better if college were cheaper," Apr 5th 2014, CHICAGO

8. Troy Onink, "Unless You're Average, College ROI and Best Value Rankings Are misleading," Forbes Contributor, July 31, 2015 